\title{
Homozygous V/V (677C to T) and D/D (2756G to A) variants in the methylenetetrahydrofolate and methionine synthase genes in a case of hyperhomocysteinemia with stroke at young age
}

\author{
Kyung Soon Song ${ }^{1,2}$, Jae Woo Song ${ }^{1}$, \\ Jong Rak Choi ${ }^{1}$, Hyun Kyung Kim ${ }^{1}$, \\ Jung Sik Shin ${ }^{1}$ and Jeong Ho Kim ${ }^{1}$ \\ ${ }^{1}$ Department of Clinical Pathology, Yonsei University College of \\ Medicine, CPO Box 1217, Seoul, Korea \\ ${ }^{2}$ Corresponding author: Tel, +82-2-3497-3531; \\ Fax, +82-2-3462-9483; E-mail, kssong@yumc.yonsei.ac.kr
}

Accepted 4 June, 2001

\begin{abstract}
Hyperhomocysteinemia is known to be associated with an increased risk of myocardial infarction, stroke, peripheral arterial disease, and venous thrombosis. Gene polymorphisms in methylenetetrahydrofolate reductase (MTHFR) and methionine synthase (MS) may account for reduced enzyme activity and hyperhomocysteinemia. A recent study has documented evidence of polygenic regulation of plasma homocyteine. We report here on a case of occlusive stroke at young age and hyperhomocysteinemia with homozygous V/V (677C to $T$ ) variant in the MTHFR gene as well as homozygous D/D (2756G to $A$ ) variant in the MS gene.
\end{abstract}

Keywords: methylenetetrahydrofolate reductase, methionine synthase, homocysteine, stroke

\section{Introduction}

Hyperhomocysteinemia is known to be associated with risk or severity of cardiovascular diseases and cerebrovascular diseases (Wilcken and Wilcken, 1976; Stampfer et al., 1992; Boushey et al., 1995; Perry et al., 1995). Biochemically, homocysteine is a naturally occurring sulfhydryl amino acid and its metabolism is regulated by two major pathways, re-methylation to methionine and trans-sulfuration to cysteine (Harmon et al., 1996). The conversion of homocysteine to methionine occurs through re-methylation step with $\mathrm{N}^{5}$-methyl-tetrahydrofolate, which is formed from $\mathrm{N}^{5}, \mathrm{~N}^{10}$-methylene-tetrahydrofolate in a reaction catalyzed by methylene tetrahydrofolate reductase (MTHFR) (Makris, 2000). In addition, methionine synthase (MS) catalyzes the re-methylation of homocysteine to methionine in a methyl-cobalamine dependent reaction (Harmon et al., 1999). In the trans-sulphuration pathway, homocysteine condenses with serine to form cystathionine in a reaction catalyzed by cystathionine $\beta$ synthase (CBS) (Sacco et al., 1998).

In 1988, Kang et al. described a thermolabile variant of MTHFR that is associated with decreased enzyme activity and mildly elevated plasma homocysteine levels. The responsible mutation in the MTHFR gene, a $\mathrm{C} \rightarrow$ $\mathrm{T}$ substitution at the base pair 677 leading to the exchange of an alanine to a valine, was identified by Frosst et al. in 1995.

In 1996, Leclerc et al. identified a missense mutation of MS gene, D919G, which is common in the general population and inferred that it might lead to mild hyperhomocysteinemia with a consequent effect on vascular disease.

In the present study, we describe a case of hyperhomocysteinemia with stroke at young age with identification of homozygous V/V (677C to T) and D/D (2756G to A) variants in the MTHFR and MS genes, respectively.

\section{Materials and Methods}

Case

A 21 years old man (non-smoker) suffered from recurrent paresthesia and weakness of left arm and leg for several days. There was neither previous nor family history of thrombosis or hypertension. Brain MRI study revealed an infarct on the right basal ganglia and caudate nucleus area. Extensive search for an underlying predisposition to thrombosis was done in parallel with routine complete blood count and biochemical tests. All the results including serum cholesterol level were normal except for elevated $\mathrm{Lp}(\mathrm{a})$ (57 mg/dl; normal reference range, $<30 \mathrm{mg} / \mathrm{dl})$ and total homocysteine $(22.2 \mathrm{nM} / \mathrm{ml}$; normal reference range, 6-15 $\mathrm{nM} / \mathrm{ml}$ ) levels. Pre-therapeutic serum vitamin $B_{12}$ level was also normal (240 $\mathrm{pg} / \mathrm{ml}$; normal reference range, 190-914 pg/ml) and folate level was $2.7 \mathrm{ng} / \mathrm{ml}$, which was slightly decreased, compared with normal reference range $(>3.0 \mathrm{ng} / \mathrm{ml}$ ). DNA study was undertaken to observe the genotypes of CBS, MTHFR and MS genes. The patients' parents and one sister were also included for the genetic DNA study. Oral anticoagulant therapy was performed. 


\section{Homocysteine assay}

Homocysteine was measured 3 months after the stroke as total homocysteine (i.e., free and protein-bound forms) in fasting plasma collected in an ethylenediaminetetraacetic acid (EDTA) tube. Homocysteine was reduced by tri-n-butylphosphine and was determined by means of high-performance liquid chromatographic analysis as previously described (Araki and Sakoy, 1987).

\section{DNA study}

Genomic DNA was extracted from peripheral blood samples drawn into EDTA tubes using a commercially available DNA isolation kit (Easy-DNA, Invitrogen, USA). Polymerase chain reaction (PCR) amplification of genomic DNA was performed using specific oligonucleotide primers for MS D/G genotype, MTHFR A/V genotype, and CBS 844ins68 genotype as previously described (Morita et al., 1998; Morita et al., 1999; Tsai et al., 2000). We used digestion with Haelll and Hinfl restriction enzymes for the detection of A2756G variant of the MS gene and C677T variant of the MTHFR genes, respectively.

\section{Results}

As shown in Figures 1 and 2, the proband was found to have $\mathrm{V} / \mathrm{V}$ genotype (A222V) in the MTHFR gene polymorphism (C677T) and D/D genotype (D919G) in the MS gene polymorphism (A2756G). However, as

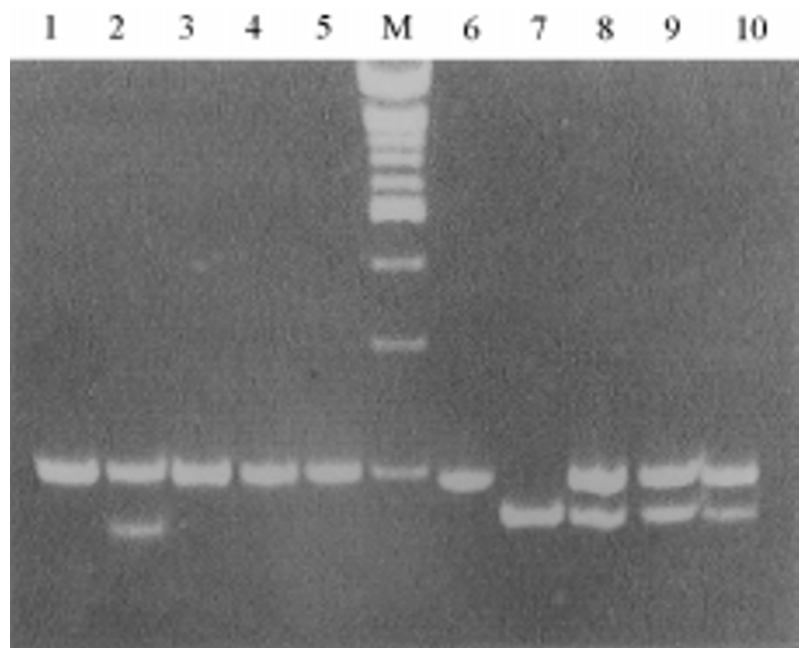

Figure 1. Restriction enzyme analysis of MS and MTHFR genes in the proband and his family. The A2756G (D919G) substitution of MS gene creates a Haelll recognition sequence which digests the $189 \mathrm{bp}$ fragment into 159 and $30 \mathrm{bp}$ fragments (Lane 1: proband, D/D; Lane 2: father, D/G; Lane 3: mother, D/D; Lane 4: sister, D/D). The C677T (A222V) substitution of MTHFR gene creates a Hinf recognition sequence which digests the 198 bp fragment into 177 and 21 bp fragments (Lane 7: proband, V/N; Lane 8: father, V/A; Lane 9: mother, V/A; Lane 10: sister, V/A). Lane 5 and 6: intact PCR products of proband before digestion. Lane M: DNA size marker, 100 bp ladder.

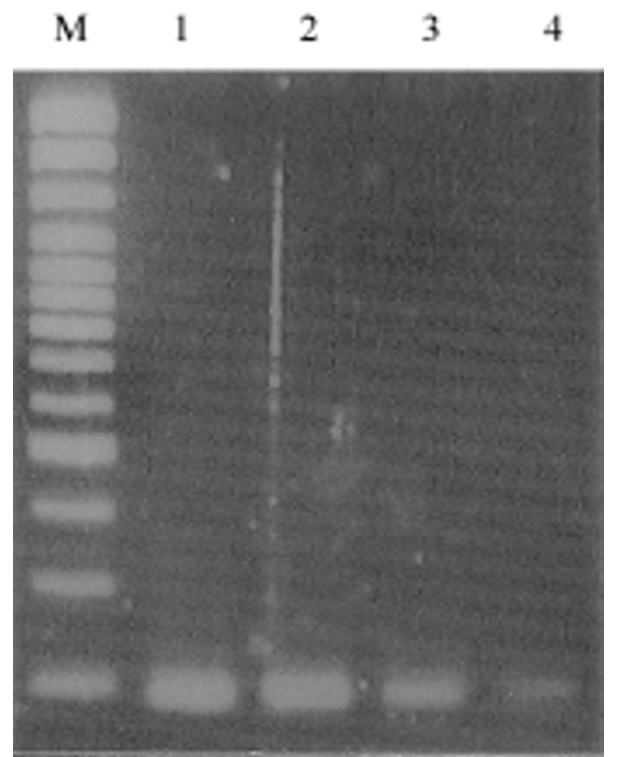

Figure 2. Polymerse chain reactions of CBS gene in the proband and his family. The 68 bp insertion (844 ins68) of CBS gene creates 252 bp instead of $184 \mathrm{bp}$ without $68 \mathrm{bp}$ insertion (Lane 1: proband; Lane 2: father; Lane 3: mother; Lane 4: sister). All the products showed no insertions. Lane M: DNA size marker, 100 bp ladder.

Table 1. MTHFR, MS, and CBS genotypes

\begin{tabular}{lccc}
\hline Genotype & $\begin{array}{c}\text { MTHFR } \\
(\text { A222V) }\end{array}$ & $\begin{array}{c}\text { MS } \\
(\text { D919G })\end{array}$ & $\begin{array}{c}\text { CBS } \\
\text { (844ins68) }\end{array}$ \\
\hline Proband & V/N & D/D & Ins68 -/- \\
Father & V/A & D/G & Ins68 -/- \\
Mother & V/A & D/D & Ins68 -/- \\
Sister & V/A & D/D & Ins68 -/- \\
\hline
\end{tabular}

MTHFR, methylene tetrahydrofolate reductase; MS, methionine synthase; CBS, cystathionine $\beta$-synthase.

shown in the Figure 2, the proband was not a carrier of 844ins68 allele of CBS gene. Genotypes of the proband as well as his family members were summarized in Table 1.

\section{Discussion}

Strokes remain as the leading cause of death in Korean population with high mortality $(80 / 100000)$, in which cerebral infarction is predominantly involved (Yoo et al., 1998). The conventional risk factors for cerebral infarction in Koreans include hypertension, smoking, hypercholesterolemia, diabetes, and aging (The Korean Neurological Association, 1993). Routine laboratory tests to detect hereditary or acquired thrombotic disorders are not warranted in older patients with stroke due to the presence of atherosclerosis of the carotid or cerebral arteries. However, in younger adults in whom there is no obvious reason for stroke, a search for an underlying predispo- 
sition to thrombosis can be fruitful and could alter therapy (Hathaway and Goodnight, 1993). As a result of clinical investigation to search any other risk factors in addition to dyslipidemia, we present a patient with an elevated plasma homocysteine level and variations in the MTHFR and MS genes, which code for key enzymes in the homocysteine metabolic pathways.

The association between homocysteinemia and stroke have been reported in previous studies (Brattstrom et al., 1990; Coull et al., 1990; Verhoef et al., 1994), and multivariate adjusted odds ratio for the highest quartile versus the lowest was 2.5 among whites (Giles et al., 1998). This association may not differ by race and the odds ratio of the highest $5 \%$ of homocysteine levels in control group in Koreans was reported to be 1.70 after an adjustment for known risk factors (Yoo et al., 1998).

A common missense mutation, $\mathrm{A} 222 \mathrm{~V}$, has been identified in the MTHFR gene, where substitution of alanine $(A)$ by valine $(V)$ results in a thermolabile variant with $50 \%$ reduced enzymatic activity at $37^{\circ} \mathrm{C}$ and complete loss of activity at $46^{\circ} \mathrm{C}$ (Kang et al., 1988; Frosst et al., 1995). This thermolabile variant has been consistently associated with mild elevations of plasma homocystein concentration (Brattstrom et al., 1998). In fact, individuals homozygous for the V222 allele were reported to have $1.6 \mathrm{nM} / \mathrm{ml}$ higher homocysteine compared to individuals with the other genotypes, and the effect of the thermolabile variant was particularly profound in the presence of low folate levels (Dekou et al., 2001). A significant decrease of blood folate concentrations in a subgroup of stroke patients who had increased plasma homocysteine concentrations has also been described (Hultberg et al., 1997). Thus the increase in plasma homocysteine concentration in the present case may partly be caused by a marginal folate deficiency. Therefore, folate supplement could have a therapeutic importance to abolish the $\mathrm{V} / \mathrm{V}$ genotype effect in the present case.

Leclerc et al. (1996) described the D919 polymorphism in the MS gene and the results from the study of healthy men have demonstrated that the D919G polymorphism has a modest effect on homcysteine levels, with carriers of the G919 allele having levels $0.6 \mathrm{nM} / \mathrm{ml}$ lower than homozygotes for the common $\mathrm{D}$ allele.

It has also been reported that carriers of the $68 \mathrm{bp}$ allele in the CBS gene had a mean homocysteine 0.8 $\mathrm{nM} / \mathrm{ml}$ lower than those lacking the allele, and in the group of men homozygous for the common D/D allele, those lacking the CBS 68 bp allele had a median homocysteine $1.0 \mathrm{nM} / \mathrm{ml}$ higher than those also carrying the 68bp allele in a genetic interaction analysis (Dekou et al., 2001). Taken together, these findings suggest that there is a biological "cross-talk" between the remethylation and the trans-sulfuration pathway in determining plasma homocysteine levels (Dekou et al., 2001). In subjects with MS D/D genotype, the odds ratio for comparing the MTHFR A/A genotype with $\mathrm{A} / \mathrm{V}$ or $\mathrm{V} /$ $\mathrm{V}$ genotype increased to 1.99 in a Japanese study to assess the association between late onset vascular disease including ischemic stroke and the A/V poymorphism of MTHFR (Morita et al., 1998). A recent study have documented the evidence of polygenic regulation of plasma homocysteine, thus providing new insights of the importance of genetic influences in carriers of common polymorphic traits, which predisposed them to either higher or lower homocysteine concentration (Tsai et al., 2000). Therefore, our case study suggests that the interactions of the CBS 68 bp allele with MTHFR V/ $\mathrm{V}$ homozygosity and with MS D/D homozygosity in determining plasma levels of homocysteine could be additive and of clinical importance, especially in the thrombotic patients at young ages. However, there appear to be no prospective data on the association of these polygenic effects on homocysteine levels with incidence or onset of ischemic stroke.

The limitation of this study is that we could not measure plasma homocysteine levels in the probands family members, which have made us impossible to observe the cosegregation of genotypes and phenotypes in this family. Anyway, the summary odds ratios of all the previous studies for patients with hyperhomocysteinemia were reported to be 2.5 for cerebrovascular disease (Markis, 2000). Therefore, additional prospective studies are needed to clarify these potential polygenic risk factors and clinical significance for stroke. In conclusion, disturbances of re-methylation enzymes (MTHFR, MS), or deficiencies of the trans-sulfuration enzyme (CBS) as well as role of genetic factors of these genes should be considered in association with hyperhomocysteinemia, particularly in thrombotic patients with no other acquired or hereditary causes (Fodinger et al., 1999; Markis, 2000).

\section{References}

Araki A, Sakoy Y. Determination of free and total homocysteine in human plasma by high-performance liquid chromatography with fluorescence detection. J Chromatogr 1987;422: 42-52

Boushey CJ, Beresford SAA, Omenn GS, Motulsky AG. A quantitative assessment of plasma homocysteine as a risk for vascular disease: probable benefits of increasing folic acid intakes. JAMA 1995;274:1049-57

Brattstrom L, Israelsson B, Norrving B, Bergqvist D, Thorne J, Hultberg B, Hamfelt A. Impaired homocysteine metabolism in early-onset cerebral and peripheral occlusive arterial disease: effect of pyridoxine and folic acid treatment. Atherosclerosis 1990;81:51-60

Brattstrom L, Wilcken DEL, Ohrvik J, Brudin L. Common methylenetetrahydrofolate reductase gene mutation leads to hyperhomocysteinemia but not to vascular disease. Circulation 1998;23:2520-26 
Coull BM, Malinow MR, Beamer N, Sexton G, Nordt F, deGarmo P. Elevated plasma homocysteine concentration as a possible independent risk factor for stroke. Stroke 1990;21: 572-76

Dekou V, Gudnason V, Hawe E, Miller G, Stansbie D, Humphries SE. Gene-environment and gene-gene interaction in the determination of plasma homocysteine levels in healthy middle-aged men. Thromb Haemost 2001;85:67-74

Fodinger M, Buchmayer H, Sunder-Plassmann G. Molecular genetics of homocysteine metabolism. Miner \& Electrolyte Metab 1999;25:269-78

Frosst P, Blom HJ, Milos R, Goyette P, Sheppard CA, Matthews RG, Boers GJ, den Heijer M, Kluijtmans LA, van den Heuvel LP. A candidate genetic risk factor for vascular disease: a common mutation in methylenetetrahydrofolate reductase. Nat Genet 1995;10:111-13

Giles WH, Croft JB, Greenlund KJ, Ford ES, Kittner SJ. Total homocyst(e)ine concentration and the likelihood of nonfatal stroke: Results from the third national health and nutrition examination survey, 1988-1994. Stroke 1998;29:2473-77

Harmon DL, Woodside JV, Yarnell JW, McMaster D, Young IS, McCrum EE, Gey KF, Whitehead AS, Evans AE. The common "thermolabile" variant of methylenetetrahydrofolate reductase is a major determinant of mild hyperhomocysteinemia. Q J Med 1996;89:571-77

Harmon DL, Shields DC, Woodside JV, McMaster D, Yarnell JW, Young IS, Peng K, Shane B, Evans AE, Whitehead AS. Methionine synthase D919G polymorphism is a significant but modest determinant of circulating homocysteine concentrations. Genet Epidemiol 1999;17:298-309

Hathaway WE, Goodnight SH. Cerebrovascular disease and thrombosis. In Disorders of hemostasis and thrombosis. 1993, pp. 422-29, McGRAW-Hill, Inc., New York

Hultberg B, Andersson A, Lindgren A. Marginal folate deficiency as a possible cause of hyperhomocysteinemia in stroke patients. Eur J Clin Chem \& Clin Biochem 1997;35:25-28

Kang SS, Zhou J, Wong PWK, Kowalisyn J, Stockosch G. Intermediate homocysteinemia: a thermolabile variant of methylenetetrahydrofolate reductase. Am J Hum Genet 1988; 43:414-21

Leclerc D, Campeau E, Goyette P, Adjalla CE, Christensen B, Ross M, Eydoux P, Rosenblatt DS, Rozen R, Gravel RA. Human methionine synthase: cDNA cloning and identification of mutations in patients of the cblG complementation group of folate/cobalamin disorders. Hum Mol Genet 1996;5:1867-74

Markris, M. Hyperhomocysteinemia and thrombosis. Clin Lab Haem 2000;22:133-43

Morita $H$, Kurihara $H$, Tsubaki S, Sugiyama T, Hamada C, Kurihara Y, Shindo T, Oh-hashi Y, Kitamura K, Yazaki Y. Methylenetetrahydrofolate reductase (MTHFR) gene polymorphism and ischemic stroke in Japanese. Arterioscler Thromb Vasc Biol 1998;18:1465-69

Morita $\mathrm{H}$, Kurihara $\mathrm{H}$, Sugiyama $\mathrm{T}$, Hamada $\mathrm{C}$, Kurihara $\mathrm{Y}$, Shindo T, Oh-hashi Y, Yazaki Y. Polymorphism of the methionine synthase gene: Association with homocysteine metabolism and late-onset vascular disease in the Japanese population. Arterioscler Thromb Vasc Biol 1999;19:298-302

Perry IJ, Refsum H, Morris RW, Ebrahim SB, Ueland PM, Shaper AG. Prospective study of serum total homocysteine concentration and risk of stroke in middle-age British men. Lancet 1995;346:1395-98

Sacco RL, Roberts JK, Jacobs BS. Homocysteine as a risk factor for ischemic stroke: an epidemiological story in evolution. Neuroepidemiology 1998;17:167-73

Stampfer MJ, Malinow MR, Willett WC, Newcomer LM, Upson $\mathrm{B}$, Ullmann D, Tishler PV, Hennekens $\mathrm{CH}$. A prospective study of plasma homocyst(e)ine and risk of myocardial infarction in US physicians. JAMA 1992;268:877-81

The Korean Neurological Assicaiton. Epidemiology of cerebrovascular disease in Korea. J Korean Med Sci 1993;8:281-89

Tsai MY, Bignell M, Yang F, Welge BG, Graham KJ, Hanson NQ. Polygenic influence on plasma homocysteine: association of two prevalent mutations, the 844ins 68 of cystathionine beta-synthase and $A(2756) G$ of methionine synthase, with lowered plasma homocysteine levels. Atherosclerosis 2000; 149:131-37

Verhoef P, Hennekens CH, Malinow RM, Kok FJ, Wilett WC, Stampfer MJ. A prospective study of plasma homocysteine and risk for ischemic stroke. Stroke 1994;25:1924-30

Wilcken DEL, Wilcken $\mathrm{B}$. The pathogenesis of coronary artery disease: a possible role for methionine metabolism. J Clin Invest 1976;57:1079-82

Yoo JH, Chung CS, Kang SS. Relation of plasma homocyst(e)ine to cerebral infarction and cerebral atherosclerosis. Stroke 1998;29:2478-83 